\title{
The struggle for legitimacy: language provision in two 'residual' comprehensive high schools in Australia
}

\begin{abstract}
Despite the contemporary policy rhetoric of global citizenry and the importance of languages and intercultural capabilities, language learning in Australian schools struggles for recognition and support. The curriculum marginalisation of languages, however, is uneven, affecting some school sectors more than others. In this paper we examine the provision of languages in two government comprehensive high schools, both low socio-economic status (SES), located in urban areas in New South Wales, Australia's largest state. They are termed 'residual' high schools because they cater for the students remaining in the local schools while others attend either private or selective government high schools. We provide a qualitative picture of language provision in these two schools from the perspectives of key stakeholders - school principals, teachers, students and parents. We also draw on observational data of language classes. The aim is to provide, within a largely social class framework, an understanding of the state of language provision in these schools. We argue that currently students in these schools are experiencing unequal access to the linguistic and cultural capital associated with language learning relative to students in more privileged communities and schools.
\end{abstract}

Keywords: language learning, language teaching, neoliberalism, socio-economic status, social class

\section{Word length: 8010}

\section{Introduction: Language provision in decline}

Despite the contemporary policy rhetoric of global citizenry and the importance of languages and intercultural capabilities, both internationally (e.g. UNESCO, 2009) and in the Australian school curriculum (Australian Curriculum, Assessment and Reporting Authority, 2013), language learning in schools struggles for recognition and support. The poor status of language provision, low completion rates, and the decline in terms of 'the number of languages taught, their durations, spread and level of seriousness' in Australian schools is well recognised (Lo Bianco \& Slaughter, 2009, p. 1). Recently, Norris and Coutas (2014, p. 45) have described languages as having a 'Cinderella' status in the school curriculum because of the way they struggle for recognition, and Scarino (2014, p. 290) and others (Lo Bianco \& Slaughter, 2009, p. 1) refer to the 'fragility' of languages in school education.

This has not always been the case, nor is it uniform across schools. Until the 1960s languages such as French, Latin and German were markers of academic excellence in elite schools with 40 per cent of students taking languages for university entry (Teese \& Polesel, 2003). The development of comprehensive schools saw languages as a key part of their curriculum and 
the rhetoric of 'languages for all' accompanied wider languages learning goals of travel, career and intercultural understanding (Lo Bianco \& Slaughter 2009). In Australia, the government student enrolment from diverse language backgrounds resulting from the postwar migration program led to the introduction of community languages such as Italian and Modern Greek. For many students in lower-SES schools the goal of language maintenance also provided pathways to tertiary study. By the year 2000 the number of students studying languages had increased by 500 per cent on the figures from 50 years before (Teese $\&$ Polesel, 2003).

However, following several decades of the neoliberal ideology of school choice (Ball, 2006), the decline of the comprehensive system and the consequent increase in the marketisation of 'specialist' schools and the expansion of non-government schools has seen a shift in the role of languages in government policy and the value accorded languages in schools. Government policy and funding have shifted to privilege languages of trade and Asian languages. At the same time, some European languages such as French and Italian, continued to hold their value in the more traditional, disciplinary-based curriculum of elite private and middle class selective government schools, drawing on discourses of global citizenship and preparation for employment in an international marketplace (Singh \& Qi, 2013; Smala, Bergas Paz \& Lingard, 2013). In contrast, languages in government comprehensive schools have struggled in the context of imperatives to improve literacy and numeracy and the employability of their students.

In this paper we examine how this plays out in two government comprehensive (nonselective) schools in which the students are predominantly from low SES backgrounds based on the Index of Community Socio-Educational Advantage (ICSEA ${ }^{\mathrm{i}}$, see Department of Education and Training, 2010). Both schools reflect the general trend in comprehensive secondary schools in NSW to limit language teaching to the mandatory 100 hours, however they differ in the choice of, and argument for, language provision and in the pedagogies employed. We argue, however, that despite these differences the schools are still illustrative of the contexts in which languages struggle for recognition in comprehensive schools and, in one school, how students' language identities and linguistic capital are not taken into account in choices of and approaches to teaching languages. In doing so our research addresses the relative absence of studies of social class in the field of applied linguistics compared with the other identity categories of ethnicity, race and gender (Block, 2014; Darvin \& Norton, 2014; Kanno, 2014) and points to the ways in which language opportunities contribute to social class differences in student outcomes and potential futures.

\section{Inequality, neoliberalism and 'residual' comprehensive high schools}

The role of social class within Australian secondary schools was examined more than 30 years ago in a seminal study by Connell et al. (1982), and while language provision did not feature specifically, their analysis remains relevant for understanding social class within contemporary secondary schooling in Australia. Connell et al. state that 'social class inequality is a massive fact of our system of secondary education' (p. 18), and their study 
demonstrated the inequalities between comprehensive high schools and private schools, and their respective working class and ruling class students. In the intervening decades these social class inequalities have been exacerbated as the 'cascading' market forces of neoliberalism have commodified education, leading to the continually increased development and patronage of both private schools and academically selective government high schools (Connell, 2013).

Understanding the effects of neoliberalism on the role and nature of government comprehensive high schools is integral to understanding language provision in this paper. These schools were created as universal providers, indeed to monopolise enrolments in local areas, and the mid-1970s represented their high point in Australia. They have struggled, however, against competitive market forces, and have been required to become more specialist, 'in fact, less comprehensive', in order to survive (Campbell \& Sherington, 2013, p. 3). Campbell and Sherington's (2013) study of comprehensive public high schools has demonstrated how some comprehensives have failed to survive, especially in inner city areas, and others have experienced declining enrolments and have become 'residual' schools following the loss of students through the creaming effects of selective testing and local students attending private/independent schools. Correspondingly, there has been a 'class shift' as the social and economic status (SES) of comprehensive high school populations (based on parental incomes and educational qualifications) has declined relative to those attending private/independent schools in an era of school choice and parental anxieties and aspirations for the competitive advantage of their children (Campbell, Proctor \& Sherington, 2009). As studies have shown (e.g. Perry \& McConney, 2010), the lower the SES of schools, the lower the educational outcomes for students.

\section{Reduced access to the academic curriculum and consequences for language provision}

An outcome of this differentiated schooling process brought about through the competitive effects of neoliberal policy is that low SES government secondary schools may provide reduced access to the academic curriculum that is important for university entry, an issue of importance for both economic and social justice reasons (Perry \& Southwell, 2013). Perry and Southwell (2013, p. 468) define the academic curriculum as 'disciplinary-based knowledge' in humanities (which includes languages), mathematics, natural sciences and social sciences. Declining enrolments in many of these schools 'forces principals to make hard decisions about what subjects they choose to offer their students' (p. 480). For the lowest SES ranked schools (the bottom 20 per cent on the ICSEA ranking scale), access to the academic curriculum 'is severely curtailed' (p. 480). These findings need to be understood in combination with other studies that demonstrate 'curriculum matters' in terms of opportunities for the social mobility of students from different social classes (e.g. Iannelli, 2013).

We argue that languages are one of the components of the academic curriculum that 'matters' and their relative absence in government comprehensive schools serving the less affluent contributes to the further polarisation of social and economic inequalities/gap between the 
rich and poor in Australian society, through differentiated access to linguistic capital. Languages in elite independent schools and many of the burgeoning secular independent schools (e.g. bilingual and international grammar schools) promote languages because they see learning a second language (trade or prestige) as contributing to the development of multilingual global citizens (Smala et al., 2013; Author 2, Author 1, Author 3 in press).

The phenomenon of high stakes testing, and in particular NAPLAN (National Assessment Program - Literacy and Numeracy), the nationwide testing of students in school years 3, 5, 7 and 9 for their literacy and numeracy skills, has also impacted access to the academic curriculum in low SES schools. Invariably, students from low SES areas perform less well on these tests, and thus their impact is most keenly felt in their schools (Thompson \& Harbaugh, 2013). The resulting prioritisation of basic skills and teaching to the test distorts pedagogical practices and the school curriculum, 'leading to a reduction in time spent on other curriculum areas' (Polesel, Rice \& Dulfer, 2014, p. 640). Similarly in schools in the United States the focus on testing basic skills following the No Child Left Behind legislation has been found to marginalise language provision (Rhodes \& Pufahl, 2010).

\section{Classed pedagogies}

It is not only what is taught at school that matters and is related to social class, but how. Lupton and Hempel-Jorgensen (2012) and others (Dunne \& Gazeley, 2008; Lingard \& Mills, 2007) explain that some pedagogical approaches in schools contribute more to socially just outcomes than others, and these approaches vary depending on the social class of schools. From a review of the literature they identify the pedagogical characteristics of more socially just schooling that include: high teacher agency and autonomy; connecting well with students' lives; intellectual engagement in the classroom; and creative and risk taking activities. Learning is seen to be 'for the sake of learning rather than a more instrumental approach', and there is a belief that all students 'are capable of transformation' in their learning (Lupton \& Hempel-Jorgensen, 2012, p. 603). However, pedagogical approaches in the working class (primary) schools researched by Lupton and Hempel-Jorgensen often appeared removed from the above approaches. These approaches included:

strong classification and framing so that students know what they are supposed to be learning and can be kept on task, whole-class teacher-led activities in which the teacher can maintain surveillance and control, seating strategies, short and superficial activities which do not allow the possibility of going off task and extensive behaviour management measures (p. 611).

Lupton and Hempel-Jorgensen identify a number of constraining factors to explain the above pedagogical approaches in working class schools. These include the mismatch between the complex range of learning, social and emotional needs of students and of schools designed and resourced according to middle class norms which fail to properly take account of the social and educational consequences of material poverty. Lupton and Hempel-Jorgensen conclude that the demands on classroom teachers 'are simply much greater than in middle 
class schools' and that teachers 'tend to fall back into modes of pedagogy with which they can, in various senses, succeed' (p. 611).

Another explanation for differential pedagogies in working class schools relates to teacher identities and how teachers view their students. Drawing on the work of Reay (2006), Lupton and Hempel-Jorgensen (2012, p. 612) argue that teachers 'approach teaching in working class schools from an unacknowledged position of middle class normality', and thus working class students are often seen in terms of deficits, based on these norms.

It is in this context that we consider the effects of neoliberal policies on the place of languages in the curriculum of two low SES comprehensive schools, how languages are taught, and how this might be both a consequence of the social class of the students and contribute to further social inequalities. We also point to the possibilities for making a difference, but acknowledge how such possibilities are limited by contemporary language policies and institutional and bureaucratic practices.

\section{The study and research method}

The data analysed in this paper are derived from a much larger study of language provision in two urban areas in NSW (Author 3, 2, forthcoming) involving 52 schools across several jurisdictions and levels. The two schools selected for analysis in this paper, which we call Cosmo High School and Metro High School (pseudonyms), are examples of state government comprehensive high schools with low SES students (based on ICSEA rankings). Cosmo HS is in a regional city, and Metro HS is in an inner city area within the state capital. They both fell below the average ICSEA score for schools, and were the lowest ranked secondary schools in our larger study. Data were collected in these schools by a small team of researchers visiting the schools several times (at least three visits to each school). The research methodology was primarily qualitative. At each school the principal was interviewed and also the language teachers and, when available, non-language teachers in the schools. All interviews were semi-structured, recorded, and later transcribed in full. Small groups of students were also interviewed (three small groups at one school, one larger group approximately 10 students, in the other), in the manner of focus groups. Where possible parents were also interviewed. Language classes were also observed, usually involving two researchers in the classroom taking field notes. These classes were not recorded. Research ethics approval for this study was obtained through the University of Sydney.

The data for this paper are derived primarily from transcripts of interviews with the teachers, students and principals and from field notes. These data for each school were read closely by three researchers and coded for relevant themes. These themes included: declining enrolments and their effects on language provision; the rationale for and perceived benefits of language study; perceptions of students and their families; and language pedagogies. We begin with a brief description of the communities served by the comprehensive high schools, followed by an analysis of language provision at each of the two schools in the context of 
contemporary language discourses and theorisations of social impacts on curriculum and pedagogies.

\section{Two local communities}

As we demonstrate in following sections, both of the schools we have chosen to focus on for this paper could be categorised as 'residual' government comprehensive high schools, and not surprisingly the students live predominantly in the local catchment areas. This contrasts with academically selective high schools and private schools in our larger study, where many of their students live out of area. Metro, the location of one of the schools, is a large innercity suburb (population 24,500) with a high percentage of people (43 per cent) who speak a language other than English at home (Australian Bureau of Statistics, 2011). These languages, in order of number of speakers are: Greek, Vietnamese, Arabic and Portuguese. Cosmo, the location of the other school, is a smaller suburb in a regional city (population 6,400) with a smaller percentage speaking a language other than English at home (14 per cent). These main languages are Italian, Arabic and Macedonian. The community language trends in both suburbs are reflected to some degree in the composition of the school student populations, with 81 per cent and 13 per cent respectively of students at Metro HS and Cosmo HS having language backgrounds other than English (<http://www.myschool.edu.au/>). Other census data to note in Metro and Cosmo respectively are the percentage of low income households (less than $\$ 600$ per week) - 20 per cent and 29 per cent; the percentage of renters - 33 per cent and 20 per cent; and social housing -6 per cent and 8 per cent. Both suburbs have a mix of occupations, with Metro showing a recent trend of more professionals moving into the suburb, reflecting a 'gentrification' process based mainly on its close proximity to the city centre.

\section{Two 'residual' comprehensive high schools}

The 'residual' nature of the two schools was evident from their low and declining enrolments but also from the comments of the two school principals for whom it was a defining feature of their schools. Both principals explained that they were struggling to maintain student numbers, with less than 400 students at Metro HS and less than 500 at Cosmo HS at the time of the study. At Metro, according to one experienced teacher at the school, in the 1980s there were 1200 students. Low student numbers at both schools were explained in the context of the competitive, market-based pressures of selective schooling and increased parental choice. At Metro HS for example, the principal stated, 'I've got a school where I'm surrounded by selective schools. I'm within 10 kilometres, I think there's five or six either partially or fully selective high schools, so they draw away the more academic students'. As a consequence the principal claimed, 'the community doesn't send their kids here because we're perceived as a tough school'. At Cosmo HS the principal similarly claimed 'my school has been seen as being a refuge, welfare, school of last resort'. These two declining and 'last resort' comprehensive high schools, surrounded by apparently thriving selective and private schools, are a manifestation of the competitive neoliberal ideology of school competition and choice 
outlined earlier, which has seen the decline generally of government comprehensive high schools as the dominant providers of secondary education (Campbell \& Sherington, 2013).

This is the context in which certain choices were made about language provision in each of the schools, though as we will explain, despite these 'residual' commonalities, there were also some important differences in their approaches to language provision.

\section{Languages at Metro HS}

The mandatory 100 hours of language provision at Metro HS comprised Italian in Year 8, with the possibility of studying the language as an elective subject in Years 9 and 10, although insufficient student numbers precluded it being taught as an elective in the year of this research. Maintaining enough students (a minimum 10 students were needed) for an elective Italian class in Year 9 was highly problematic given the small student numbers in the school and competition from other subjects; the principal said he would need to 'massage' the numbers to try to keep the elective class going in future years. One experienced teacher at the school claimed the decline in languages taught at the school was 'purely enrolments', and that 'when we were 1200 students, 800, 700, 500 you could still offer languages. Beyond that you just do the mandatory year 8 '.

The rationale for providing Italian as the mandatory language was entirely pragmatic. The school was obliged to deliver a language, and the language of their designated qualified language teacher happened to be Italian. The previous language teacher at the school taught Indonesian for the same reason, and in the principal's previous school it had been German, 'because that's what the languages teacher taught' (principal's comment). The principal explained the benefits of language study in ways that were aligned with1980s discourses constituting language study as valuable for travel or cultural understanding. The lack of any one dominant community language group meant that offering a community language or languages in the school was a challenging proposition. With the link of languages to the 1950s elite curriculum broken, the choice of language thus became entirely pragmatic, a response to a government imperative, rather than based on any clear rationale or goal.

The students at the school, however, were rich in language resources. While not one of the students in the focus groups was of Italian background, or even knew anyone who was Italian (beyond their Italian teacher), linguistic diversity was a feature of the school population with over 80 per cent of students speaking languages other than English at home. A snapshot of the extent and diversity of the students' home languages was provided in a discussion with a group of ten mainly year 8 students, several of whom were born in West Africa. They said they spoke several languages, including Temne, Susu, Mende and Krio, and also had some knowledge of French learnt when they attended West African schools. Some students, in particular from Vietnamese backgrounds, were studying their home language in community language programs, mainly on weekends. Two students, both from Vietnamese backgrounds, were also studying different languages (Filipino and Japanese) privately via the internet and simply out of interest. Only one of the ten students in the discussion group spoke only 
English, and for this he became the subject of (good natured) jests from the other students. The students generally seemed ambivalent towards Italian being taught as the sole foreign language in the school. Several students said they studied the subject because of the teacher, with one stating it was 'fun because the teacher's really cool ... she never gets angry, all the time she's smiling'. They could see some value in learning Italian for travelling purposes, and meeting the occasional Italian speaker and knowing about the food and landmarks, but this was expressed as a rather vague, long term possibility.

The Italian language teacher, Carly (pseudonym), was a young, inexperienced teacher in her first full time appointment at a school. She was the sole language teacher in the school. While supporting her personally, from her perspective, her colleagues did not understand language as a discipline and saw languages in the curriculum as 'a curriculum filler'. She commented that to talk about her subject with other teachers at the school 'would be a very one-sided conversation'. While Carly was aware of professional language teaching networks, and was on an Italian teachers' mailing list, she sought little direct professional support from these networks.

While passionate about languages (Italian was her home language and she was also qualified to teach Spanish), Carly struggled to inspire the same enthusiasm for Italian in her students. She commented, for example, that if students chose to do Italian as an elective subject, they did it 'not for academic reasons, for social reasons, like my friends are doing it, or that teacher might not yell at me as much as that teacher'. To some extent Carly herself saw problems with teaching Italian. She suggested that the reason for learning a language these days was 'very much business-driven' with Asian languages in demand, 'killing out the Latin ones'. Hence, while she personally saw Italian as 'great for opening doors and just knowing there's a world outside our boundaries', she perceived that others (in her school at least) saw little value in it.

There were also few incentives for her students to continue studying Italian to the senior level and final school exams. Carly admitted to actively discouraging those of her students who took the Italian elective in Years 9 and 10 from continuing with their study, because they would struggle to be competitive in a system in which they would be required to study the Italian Continuers course (i.e. not Beginners ${ }^{i i}$ ), having studied the language beyond the mandatory 100 hours. Thus they could be competing against students who spoke Italian at home as well as studying the language for most of their secondary schooling.

Like other teachers in working class schools, as described earlier by Lupton and HempelJorgensen (2012), Carly, attributed the students' lack of interest in her subject as a function of abilities related to their life circumstances ('generally speaking, a lot of lower socioeconomic parents are uneducated or in situations where they lack access to resources and knowledge'). She described students as 'not particularly studious' and not prepared for the kind of commitment that language study required, 'languages is just something that you have to constantly, constantly expose yourself to and engage with'. Furthermore, she felt that the 
students' English skills were 'not strong to begin with' which was seen to limit their ability to learn Italian. Carly acknowledged that her own formal schooling experiences left her unprepared for teaching at a working class school like Metro HS. She said she once believed that 'all students came into the classroom, sat down and waited to learn without being naughty or anything. But there are so many other things you're just completely unaware of that inhibit that dream or hinder it'. While we would suggest this is rarely the case in any school, the challenges of Metro HS were more like those described above by Lupton and Hempel-Jorgensen for the working class schools they studied. And like the teachers in that study, it was not surprising that the pedagogies we observed in Carly's classroom were those that enabled her to manage (i.e. control) her class and to have some success with her students.

In the several classes we observed Carly teaching Italian to Year 8 students, a traditional grammar translation approach was employed which kept the students engaged in written activities. There was very little spoken communication in Italian, apart from introductory lesson comments, and students remained seated in structured rows of desks. Lessons were teacher-directed using interactive whiteboard exercises, and there was a focus on grammatical worksheet exercises. As Carly acknowledged herself, her classroom practices included 'spoon-feeding' students with structured worksheet activities designed to keep them on task as 'a sort of discipline thing'.

In many respects the language pedagogy at Metro HS appeared little different to the pedagogy described in the working class schools cited earlier in the literature, and was typical of the language pedagogy we observed in a number of other schools in our larger study. At Metro HS, it may have been exacerbated through the circumstances of an inexperienced, and in a disciplinary sense, isolated teacher. It was also clear that Italian as the chosen mandatory language lacked support from key interest groups, including students and parents, and combined with the school's low enrolments and competition from other electives, it was difficult to deliver as an elective subject.

Metro HS exemplifies the conundrum evident in many low SES schools with high numbers of students with diverse language backgrounds. The marginalisation of community languages in government policy leaves these schools with no incentives, nor ways of creatively working with the language resources of their students. Ironically, in the context of middle classes discourses of multilingualism, these students' existing qualifications, as global citizens who already speak more than one language, are regarded as a handicap rather than an asset. At Metro HS, and we would argue many similar schools in Australia, it seemed to be extremely difficult to imagine futures for students in these schools beyond the immediate necessities of the vocational and integration into an English speaking Australia.

\section{Languages at Cosmo HS}

Cosmo HS presented a contrast to Metro in that there was considerable support from the school executive for the teaching of languages - at least rhetorically. However, we would argue that, at the same time, this support for languages was precarious, shaped by similar 
issues associated with a low SES comprehensive school and contingent on the efforts of an experienced [but sole] language teacher who was embedded in the school hierarchy. At the time of the study two languages were taught at Cosmo HS - Mandarin as the mandatory 100 hours language (in Year 7), and French as an elective subject in Years 9 and 10. Officially there was only one language teacher, Jack (pseudonym), an experienced teacher of German who had chosen to retrain in Mandarin, and was now committed to that language visiting China regularly and building resources and networks in Australia. A generalist teacher, Margo (pseudonym), had not long ago serendipitously picked up a senior French class for the HSC, and subsequently was able to offer a French elective in Years 9/10, which at the time of the study was running with a minimum number of students. The intention was to also offer Mandarin as an elective subject in Years 9/10, however, at the time of the research the 'numbers game' as the Mandarin teacher described it, meant there were insufficient students to enable it to run. As was the case at Metro HS, the principal was grappling with human resource issues involving departmental staffing formulas in a school with limited enrolments.

The choice of Mandarin as the mandatory 100 hours language at Cosmo HS was a deliberate decision to enhance the profile of the school, with the hope that it might be the first step in establishing the school as a designated specialist languages school. In other words, Mandarin was seen as a marketing opportunity for the school:

I think it's looking for a distinction; it's looking for something to sell. I think when you're looking at different products the different schools are selling, some schools are looking down the line of sports high schools, there are IT schools, performing arts schools. So I think it's looking for a niche. (Jack, Mandarin teacher)

Mandarin was the language of choice because, from the principal's perspective, it was the language that best met 'the future-proofing needs of our students out in the employment force'. He argued that Mandarin would 'set them up for employability over other people and that's important'. Similarly, Jack, the specialist language teacher, elevated Mandarin as 'the way to go', due to the prominence of China in world affairs and in the Australian economy with future employment opportunities. To a large degree therefore, the principal and his language teacher appeared intent on establishing Mandarin in their school as a 'marker of distinction in the school market' (see Smala et al., 2013). This was the message they were trying to sell to parents.

From our interviews with the parents this particular message was not evident. Rather the parents' views on the value of languages were mixed with one parent commenting that, '[f]oreign languages are foreign to kids. They don't have to learn other languages. They don't necessarily hear other languages as such, unless your parents are foreign'. Another suggested that in the best interests of her son, her curriculum priorities lay elsewhere, '... as I said, I tend to prioritise the reading, writing and arithmetic higher than the Mandarin'. A third was more positive, drawing on a discourse of understanding others, rather than the vocational value of languages, 'it does open your mind, your eyes and your ears to other people'. 
The difficulty for the principal in trying to promote Mandarin in the school was that, at the time of the study, elective classes could not be delivered in Years 9 and 10 due to insufficient numbers of students electing to do the subject. Several factors may have contributed to this, including the small student population at the school, the lack of continuity in teaching Mandarin from Year 7 (no languages were offered in Year 8), and competition from a range of other elective subjects, including sports, industrial arts, and another language, French (though in the year following the study, according to an email from the language teacher, the school was able to deliver Mandarin).

The cultural and linguistic diversity of the student population at Cosmo HS was much less than that at Metro HS. Only 14 per cent (compared with 81 per cent at Metro HS) spoke a language other than English at home, but the range of languages within immediate or extended families was nevertheless quite extensive. A group of students mentioned backgrounds in, and/or some family members speaking: Danish, Serbian, Vietnamese, Indonesian, Malaysian, French, and Hungarian. Student motivation for studying languages at Cosmo HS was a little difficult to identify. For example, there were students who appeared to read from the Mandarin teacher's script, with one student claiming 'China's our future, like come on' (Year 9 student). But when asked if any students knew anyone who was Chinese, the one student who answered in the affirmative commented 'only you', referring to one of the researchers. One student who had elected to do French in Year 9 commented 'I just like the culture and friends and stuff and I just thought learn a different language ... just something new to learn'. As with students at Metro HS, there seemed to be an indeterminate belief that languages would be good for travelling one day, and was 'something to back you up as a job career future thing'.

It was the teaching of Mandarin, however, that marked a sharp contrast in language provision at the two schools, and this had much to do with Jack's personal approach and teaching style. Jack brought considerable experience in language teaching, albeit originally German, and a passion for teaching and promoting Mandarin at the school. Observations of his classes indicated that he employed a communicative language approach (e.g. Nunan, 1991) that also addressed the key elements of the productive pedagogies framework, as outlined by Mills et al. (2009): intellectual quality, connectedness a supportive classroom environment and valuing and working with difference.

The expectations for student learning were explicitly articulated on a chart on the wall, with achievement goals for a hierarchy of levels, with each level having a variety of tasks to be achieved. The students explained these with some enthusiasm to the researchers and seemed to regard them as an achievable guide to their progress. Communicative activities in Mandarin, with lots of spoken work, authentic language opportunities, and challenging calligraphy tasks, formed the basis of Jack's pedagogy. More competent students were encouraged to work in pairs with less competent students, and students moved around the classroom engaged in a range of different activities, including interactive games (often computer-based) and brush painting (calligraphy). One researcher described the atmosphere in his class as, 'fun, engaging, collaborative, supportive'. Jack frequently spoke Mandarin 
when addressing the students, and in one activity they were asked to individually introduce themselves (to the Chinese researcher) in Mandarin. For Jack, student 'engagement' in the language and Chinese culture was fundamental to his purpose to make Mandarin meaningful to their lives. He used school excursions to Chinatown, stories and photographs of his own experience in China, and visits by native Chinese speakers.

The other language taught as an elective subject in Years 9/10 at the school, French, was described by the researchers as taught in a 'traditional' way. Researcher notes described it as involving a lot of English to French translation and 'choral repetition' where students repeated aloud after the teacher. According to the school principal, the elective French classes at Cosmo HS appeared to attract more academically-oriented students, those with 'tertiary aspirations ... the sort of kids you want to see in any class'.

In summary, language provision at Cosmo HS was more extensive than at Metro HS in that, in addition to the mandatory 100 hours in Mandarin, there was a French elective in Years 9/10, operating with minimum student numbers. However, the big differences at Cosmo HS were the strong promotion of Mandarin by the principal and the language teacher, and the way it was taught. Mandarin was promoted as a marketing/selling point for the school - a 'marker of distinction', though at this early stage (Mandarin had only been introduced for the past three years), it was unclear that others in the school community, in particular parents and students, shared this vision. In addition, small school enrolments and competition from other elective subjects continued to make it difficult to offer the subject beyond the mandatory 100 hours in Year 7. Unlike at Metro HS, the language teacher, Jack was very experienced, and adopted a student-centred 'communicative language teaching' approach that challenged his students in a supportive environment. His aim was to make Mandarin meaningful for his students, to link it with the outside world as a language of 'trade' (Lo Bianco \& Slaughter, 2009), with a focus on both communicative competence and culture, potentially opening up employment opportunities. French on the other hand was a traditional academic language taught at the school (and taught in a fairly traditional way).

\section{Conclusions}

The decline of the government comprehensive high schools and the concomitant shift of emphasis in comprehensive low SES schools away from an academic curriculum have impacted the place of languages in these schools. The assumption that students in these schools are neither capable nor interested in languages is a consequence we argue of more generalised assumptions about students in such schools as requiring remediation (Darvin \& Norton, 2014; Lingard \& Mills, 2007). This is exemplified particularly in 'residual' schools such as those described in this paper, which have in many ways been abandoned both by middle class parents and students and state education bureaucracies.

The struggle of languages for legitimacy is exacerbated in a context where the very existence of comprehensive high schools is challenged by the impact of high stakes testing and parent choice. At the same time language policy which privileges a discourse of trade languages and 
Asian languages which are valuable in the global marketplace, elides a multicultural discourse which recognises the language resources and capabilities of new immigrants and students from diverse cultural and linguistic backgrounds. While this multicultural language discourse prevailed in the late $70 \mathrm{~s}$ and $80 \mathrm{~s}$, it was replaced by a 'monolingual mindset' (Clyne, 2008), and a discourse of 'English literacy first' that began with the national language and literacy policies of the early 1990s (Lo Bianco, 2001). The impact of this discourse was particularly evident at Metro HS, where students' background languages were seen to limit their proficiency in English and where there was no recognition of the value of knowing more than one language in learning another language including English. The Metro HS principal's priority was the preparation of students for integration into the Australian workforce through educating for basic literacy and numeracy. In this context language study, beyond the 100 hours mandated by government policy, was not a priority.

In contrast, the promotion of Mandarin, at Cosmo HS seemed to reflect a human capital discourse (symbolised as 'profit') associated with the push for Asian languages in 'the Asian century'. While the Mandarin classes at Cosmo HS demonstrate the possibilities for language study in working class comprehensive schools, we would still argue that the survival of languages in this school depends on the activity and leadership of one teacher and that their continued existence beyond the mandatory 100 hours remains precarious. While there are comprehensive schools in NSW and elsewhere in Australia which continue to support a greater range of languages and attempt to be responsive to the language backgrounds and capabilities of their students, from the evidence of our study, languages in these schools are still vulnerable, dependent on the passion of experienced language teachers and the goodwill of principals.

As many researchers now point out, what Haberman (1991) describes as 'pedagogies of poverty', that is, those focused almost exclusively on the maintenance of order through classroom technique (see also Lupton and Hempel-Jorgensen, 2012; Lingard \& Mills, 2007) potentially limit possibilities for learning in disadvantaged schools. In the case of the two classes described in this paper, this was most apparent in the pedagogy in the Italian classroom. Like many similar schools, there was only one designated language teacher and she was in her third year of teaching with little support from the school for her subject, and a school context in which the students were understood as not academically inclined and in need of control. In contrast, the pedagogy in the Mandarin classes demonstrated the possibilities for 'teaching otherwise', by taking a student-centred, communicative approach that in a number of respects met the criteria for 'more socially just schooling' outlined earlier in the work of Lupton and Hempel-Jorgensen (2012) and of the productive pedagogies framework described by Mills et al. (2009). We would argue that Jack's passion, experience and teaching approach had the potential to inspire achievement in, a liking of languages and a motivation for further study in his students. The organisation of the language curriculum, however, with a year gap before students had the opportunity to choose a language elective, meant that the provision of Mandarin beyond the mandatory hours was likely to continue to be precarious. 
We argue that without national and state government policy and institutional support beyond the school, language study, in a system driven by the market, will remain an entitlement available only to students attending government schools in affluent areas and private schools. The language provision in the working class high schools in our study contrasted markedly with the language provision offered in the middle class high schools - in particular, academically selective high schools and private schools and the status accorded languages in these schools (see Author $3 \& 2$, forthcoming; Author 2, 1, 3, forthcoming). In these schools, a recognition of the value of language study was evident in their prospectuses, in the promotion of languages as an integral component of the school curriculum at all levels, (Authors forthcoming) and in some states in the institution of and popularity of bilingual schools amongst the middle class (Smala et al., 2013). In these schools a second language is advocated as necessary to the education of global citizens, whether this be for the instrumental purposes embodied in trade languages or more comprehensive constructions of global citizenship as exemplified in programs such as the International Baccalaureate (Singh \& Qi, 2013)

Our argument to this point has been to demonstrate how differences in language provision contribute to social inequalities through case studies of two schools. However, it is important not to imply that we are arguing simply for more languages in working class schools on the basis of a deficit of opportunities for employment and chances of university entry. While this is certainly part of the story, we argue for languages as an essential component of any schooling that values respect for others through learning about different cultures and different ways of knowing and thinking. Learning a second or third language (well), we would argue, contributes to the development of the kinds of dispositions necessary for respect of the 'other', in a country and world characterised by diverse cultures (Resnick, 2009).

In a context in which there is an absence of studies examining the relationship between language policy, social class and its effects (Block, 2014), this paper sought to exemplify the struggle languages have for legitimacy in many comprehensive high schools in Australia and how this contributes to social inequalities. Following Block (2014), we argue that more research is required to comprehensively examine the ways in which language policy and its translation into schools intersect with, and contribute to, social class differences and inequalities in Australia and more widely. In addition, research is required to explore the ways in the cultural and linguistic diversity of students in comprehensive high schools might be understood not as a problem affecting their proficiency in English, but as a source of human, social and cultural capital currently untapped in the school system.

\section{References}

Australian Bureau of Statistics. (2011). Australian social trends: Using statistics to paint a picture of Australian society. Canberra: Australian Bureau of Statistics. 
Australian Curriculum, Assessment and Reporting Authority. (2013) General capabilities in the Australian curriculum. Retrieved from http://www.australiancurriculum.edu.au/GeneralCapabilities/Pdf/Overview

Ball, S. (2006). Education policy and social class: The selected work of Stephen J Ball. London: Routledge.

Block, D, (2014). Social class in applied linguistics. London: Routledge.

Campbell, C., Proctor, H., \& Sherington, G. (2009). School choice: How parents negotiate the new school market in Australia. Sydney: Allen \& Unwin.

Campbell, C., \& Sherington, G. (2013). The comprehensive public high school: Historical perspectives. New York, NY: Palgrave Macmillan.

Clyne, M. (2008). The monolingual mindset as an impediment to the development of plurilingual potential. Sociolinguistic Studies, 2(3), 347-366. doi: $\underline{10.1558 / \text { sols.v2i3.347 }}$

Connell, R., Ashendon, D., Kessler, S., \& Dowsett, G. (1982). Making the difference: Schools, families and social division. Sydney: Allen \& Unwin.

Connell, R. (2013). The neoliberal cascade and education: An essay on the market agenda and its consequences. Critical Studies in Education, 54(2), 99-112. doi:10.1080/17508487.2013.776990

Darvin, R., \& Norton, B. (2014). Social class, identity, and migrant students. Journal of Language, Identity and Education, 13(2), 111-117. doi: 10.1080/15348458.2014.901823

Department of Education and Training. (2010). Explaining ICSEA. Retrieved from http://www.schools.nsw.edu.au/media/downloads/schoolsweb/news/announcements/ yr2010/jan/what_is_icsea.pdf

Dunne, M., \& Gazeley, L. (2008). Teachers, social class and underachievement. British Journal of Sociology of Education, 29(5), 451-463. doi: $10.1080 / 01425690802263627$

Haberman, M. (1991). Pedagogy of poverty versus good teaching, Phi Delta Kappan, 73, 290-94.

Iannelli, C. (2013). The role of the school curriculum in social mobility. British Journal of the Sociology of Education, 34(5-6), 907-928. doi:

$10.1080 / 01425692.2013 .816031$

Kanno, Y. (2014). Forum commentary. Journal of Language, Identity \& Education, 13(2), 118-123. doi: 10.1080/15348458.2014.901825

Lingard, B., \& Mills, M. (2007). Pedagogies making a difference: Issues of social justice and inclusion, International Journal of Social Inclusion, 11(3), 233-244, doi: 10.1080/13603110701237472

Lo Bianco, J. (2001) From policy to anti-policy: How fear of language rights took policy making out of community hands. In J. Lo Bianco \& R. Wickert (eds) 
Australian policy activism in language and literacy. (pp. 13-44). Melbourne: Language Australia.

Lo Bianco, J., \& Slaughter, Y. (2009). Second languages and Australian schooling. Camberwell: Australian Council for Educational Research.

Lupton, R., \& Hempel-Jorgensen, A. (2012). The importance of teaching: Pedagogical constraints and possibilities in working class schools. Journal of Education Policy, 27(5), 601-620. doi 10.1080/02680939.2012.710016

Mills, M., Goos, M., Keddie, K., Honan, E., Pendergast, D., Gilbert, R., Nichols, K., Renshaw, P., \& Wright, T. (2009) Productive pedagogies: A redefined methodology for analysing quality teacher practice. Australian Educational Researcher, 36(3), 6787.

Norris, L., \& Coutas, P. (2014). Cinderella's coach or just another pumpkin? Information communication technologies and the continuing marginalisation of languages in Australian schools. Australian Review of Applied Linguistics, 37(1), 43 61.

Nunan, D. (1991). Communicative tasks and the language curriculum. TESOL Quarterly, 25(2), 279-295.

Perry, L., \& McConney, A. (2010). School socio-economic composition and student outcomes in Australia: Implications for educational policy. Australian Journal of Education, 54(1), 72-85. doi: 10.1177/000494411005400106

Perry, L., \& Southwell, L. (2013). Access to academic curriculum in Australian secondary schools: A case study of a highly marketised education system. Journal of Education Policy, 29(4), 467-485. doi: 10.1080/02680939.2013.846414

Polesel, J., Rice'S., \& Dulfer, N. (2014). The impact of high-stakes testing on curriculum and pedagogy: A teacher perspective from Australia. Journal of Education Policy, 29(5), 640-657. doi: 10.1080/02680939.2013.865082

Reay, D. (2006). The zombie stalking English schools: Social class and educational inequality. British Journal of Sociology of Education, 54(3), 288-307.

Resnick, J. (2009). Multicultural education - good for business but not for the state? The IB curriculum and global capitalism. British Journal of Educational Studies, 57(3), 217244.

Rhodes, N. C., \& Pufahl, I. (2010). Foreign language teaching in U.S. schools: Results of a survey. Washington, DC: Centre for Applied Linguistics.

Scarino, A. (2014). Situating the challenges in current languages education policy in Australia - unlearning monolingualism. International Journal of Multilingualism, 11(3), 289-306. doi: 10.1080/14790718.2014.921176

Singh, M., \& Qi, J. (2013). 21 st century international mindedness: An exploratory study of its conceptualisation and assessment. Retrieved from:

http://www.ibo.org/globalassets/publications/ibresearch/singhqiibreport27julyfinalversion.pdf 
Smala, S., Bergas Paz, J., \& Lingard, B. (2013). Languages, cultural capital and school choice: Distinction and second-language immersion programmes. British Journal of Sociology of Education, 34(3), 373-391. doi: 10.1080/01425692.2012.722278

Teese, R., \& Polesel, J. (2003). Undemocratic schooling: Equity and quality in mass secondary education in Australia. Melbourne: Melbourne University Press.

Thompson, G., \& Harbaugh, A. (2013). A preliminary analysis of teacher perceptions of the effects of NAPLAN on pedagogy and curriculum. Australian Educational Researcher, 40(3), 299-314. doi: 10.1007/s13384-013-0093-0

UNESCO. (2009). Investing in cultural diversity and intercultural dialogue. Paris: UNESCO. Retrieved from http://unesdoc.unesco.org/images/0018/001847/184755e.pdf

Author $1 \& 2$, forthcoming

Author 2, Author1, Author 3, forthcoming.

\section{Notes}

${ }^{\mathrm{i}}$ ICSEA is a national scale of relative socio-educational advantage that enables comparisons to be made across schools. The average ICSEA value is 1000. The two schools featured in this paper fell below 1000.

ii Continuers is for Year 11 students who have typically studied the language for 200-400 hours. Beginners is for Year 11 students starting the language (previous study of less than 100 hours). 